УДК 632.4.635.21

DOI https://doi.org/10.32848/agrar.innov.2021.5.21

\title{
ВІДБІР СОРТІВ КАРТОПЛІ 3 КОМПЛЕКСНОЮ СТІЙКІСТЮ ДО ЗБУДНИКА РАКУ Synchytrium endobioticum Schilbersky Perc.
}

\author{
ЗЕЛЯ А.Г. - кандидат біологічних наук \\ https://orcid.org/0000-0002-1470-7707 \\ Українська науково-дослідна станція карантину рослин \\ Інституту захисту рослин Національної академії аграрних наук України ЗЕля Г.В. \\ - науковий співробітник \\ https://orcid.org/0000-0001-7040-1908 \\ Українська науково-дослідна станція карантину рослин \\ Інституту захисту рослин Національної академії аграрних наук України МАКАР \\ Т.Й. - молодший науковий співробітник \\ https://orcid.org/0000-0001-5432-2759 \\ Українська науково-дослідна станція карантину рослин \\ Інституту захисту рослин Національної академії аграрних наук України СОНЕЦь \\ Т.Д. - завідувач сектору \\ https://orcid.org/0000-0001-6681-0274 \\ Інститут експертизи сортів рослин \\ кИєнкО 3.Б. - кандидат сільськогосподарських наук \\ https://orcid.org/ 0000-0001-7749-0296 \\ Інститут експертизи сортів рослин
}

Постановка проблеми. Картопля є однією з найважливіших сільськогосподарських культур, яку вирощують у 150 країнах світу і вживають понад 3 млрд людей. За площею посадки вона займає четверте місце після рису, пшениці та кукурудзи. У забезпеченні людства харчуванням картопля займає друге місце за пшеницею, тому її по праву називають другим хлібом [1]. Валовий збір картоплі в Україні $(22,5$ млн т) та суттєві площі посівів (1,3 млн га) свідчать про важливість цієї культури у структурі аграрного виробництва країни та глобальній проблемі забезпечення продовольством [2].

Найбільш небезпечною хворобою картоплі $€$ рак, який викликається внутрішньоклітинним облігатним патогеном - Synchytrium endobioticum Schilbersky Percival. Він $€$ однією з основних причин значного недобору врожаю картоплі, зниження її якості як продовольчої, так і кормової культури. Характер і міра шкодочинності хвороби залежать від природно-господарських умов зони [3], рівня застосовуваної агротехніки, стійкості сорту, родючості ґрунту, впровадження прогресивних технологій, рівня ведення насінництва, системи захисних прийомів та інших чинників [4].

Рак картоплі, за даними ЄОКЗР (Європейської та Середземноморської організації карантину і захисту рослин) [5] та R.P. Baayen та ін. [6], включено до переліку карантинних захворювань 38 країн світу. До 1984 р., за даними V. Bojnansky [7], в Європі було зареєстровано 22 агресивних патотипи. Сьогодні існують відомості про поширення у світі щонайменше 39 патотипів $S$. endobioticum [8; 9]. У Німеччині, за даними E. Langerfeld, H. Stachewicz та I. Rintelen, з 1991 р. зареєстровано десять патотипів [10]. У Чехії до 1991 р. існувало два патотипи [11]. У Турції, за даними Е. Cakir та ін., зареєстровано один агресивний патотип [12]. За повідомленнями S. Ghoghoberidze та ін., у Грузії виявлено та ідентифіковано один агресивний патотип [13].
В Україні вперше збудника раку було виявлено у 1938 р. [4]. За останні роки площа вогнищ раку картоплі значно збільшилася. На 1 січня 2020 р. хвороба розповсюджена у п'яти областях, 21 районі, 225 населених пунктах, 8274 присадибних ділянках на загальній площі 2 337,96 га [14]. Найбільш висока щільність вогнищ раку та його агресивних фрорм зустрічається у Карпатському регіоні України. Сприятливі умови впливають на розвиток хвороби і разом із тим є однією з причин диференціації виду гриба і формування нових патотипів. Це явище спостерігається за монокультури картоплі, особливо за вирощування суміші різних за стійкістю до раку сортів картоплі [15].

Агресивні патотипи, що розповсюджені у гірських районах України, здатні уражати до 90\% стійкого до звичайного патотипу сортименту картоплі.

Найбільш економним та ефективним заходом боротьби проти збудника раку є впровадження в сільськогосподарське виробництво стійких проти раку сортів картоплі $[16 ; 17]$. До Державного реєстру сортів рослин, придатних для поширення в Україні на 2021 р., згідно з інформацією М.М. Фурдиги [18], занесено 196 сортів картоплі, у тому числі 85 вітчизняної селекції. Сорти відрізняються від зарубіжних аналогів високими адаптивними властивостями, стійкістю до хвороб так шкідників, посухо- та жаростійкістю, мають більш пролонгований період ефективного репродукування, високі смакові якості. Наявний сортимент сортів повністю задовольняє попит населення [19].

Мета статті. Оцінити та відібрати сорти картоплі української та іноземної селекції з комплексною стійкістю до всіх патотипів раку, що існують в Україні, та виділити стійкі сорти для занесення до Державного реєстру сортів рослин, придатних для поширення в Україні, які можна впровадити у вогнищах хвороби.

Матеріали та методи досліджень. Для досліджень із відбору стійких сортів картоплі до звичайного та 
чотирьох агресивних патотипів збудника раку в 2019-2020 рр. використовували 15 зразків картоплі: п'ять сортів української селекції - Містерія, Житниця, Опілля, та Родинна - селекції Інституту картоплярства НААН; Княжа - селекції Львівського національного університету. Десять сортів картоплі - іноземної селекції: 7 фор 7 та Прада - фрірми «Ден Хартіг Б.В.», Нідерланди; Раномі, Алюетт, Лаундин, Парадізо, Фонтане - селекції фірми «Агріко Б.В.», Нідерланди; Родріга та Ліллі - фрірми «Солана ГмбХ унд Ко, КГ.», Німеччина; Шері - фрірми «Жермікопа Брідінг САС», Франція.

Оцінку матеріалу картоплі на стійкість до звичайного і чотирьох агресивних патотипів збудника раку картоплі проводили лабораторними та польовими методами, згідно з EPPO Standard PM 7/28/1 [20] та EPPO Standard PM 7/28/2 [21].

Лабораторні досліди із зараження 15 сортів картоплі зимовими зооспорами (у субстраті ґрунт/перліт) та зараження літніми зооспорами зі свіжих ракових наростів звичайного патотипу збудника раку було закладено у березні місяці у лабораторії карантинних шкідників та хвороб УкрНДСКР ІЗР НААН (с. Бояни Новоселицького району Чернівецької області). Також було закладено лабораторні досліди з визначення стійкості зразків картоплі до агресивних патотипів збудника раку в Закарпатському опорному пункті УкрНДСКР ІЗР НААН (с. Майдан Міжгірського району Закарпатської області).

Попередню оцінку стійкості до звичайного патотипу збудника раку проводили у лабораторних умовах. Для лабораторної діагностики використовували два методи.

Результати досліджень. Першим етапом лабораторних досліджень є зараження зразків картоплі зооспорами із зимуючих зооспорангіїв збудника раку у спеціальних контейнерах (30 x 40 см) із субстратом ґрунт/перліт (1 : 1), який уміщував 50-60 зимових зооспорангіїв збудника хвороби на 1 г ґрунту. Для цього в контейнерах висаджували зразки картоплі для випробування та контрольні сорти: позитивний контроль - сорти, які уражуються збудником раку (Поліська рожева, Лорх) та негативний контроль - сорти, які не уражуються жодним патотипом збудника раку (Божедар, Глазурна) (рис. 1). Контейнери залишали у лабораторії протягом 75 діб за 60-80-відсоткової вологості, освітлення 1600 люкс 12/12 за температури $17-18^{\circ} \mathrm{C}$, через кожні три доби їх поливали, раз на тиждень проводили розпушування і через 75 діб визначали реакцію зразків картоплі на зараження збудником раку (рис. 1). Для цього рослини підкопували з контейнерів і підраховували ракові нарости з кожного дослідного зразка, а також із контрольних сортів картоплі. Результати вважали достовірними, якщо ураження контрольного сорту становило не менше $80 \%$ [22].

Другий етап передбачав зараження паростків бульб картоплі літніми зооспорами зі свіжих ракових пухлин.

Оцінку стійкості рослин за використання літніх зооспор збудника, одержаних зі свіжих ракових наростів, проводили за методикою EPPO Standard PM 7/28/1 [20] та EPPO Standard PM 7/28/2 [21]. Для цього навколо паросткової частини бульби картоплі за допомогою підігрітої суміші парафріну та вазеліну (1:1) прикріплювали паперове кільце. У кільце наливали дистильовану воду і додавали 0,5 см³ свіжого наросту раку, який уміщував

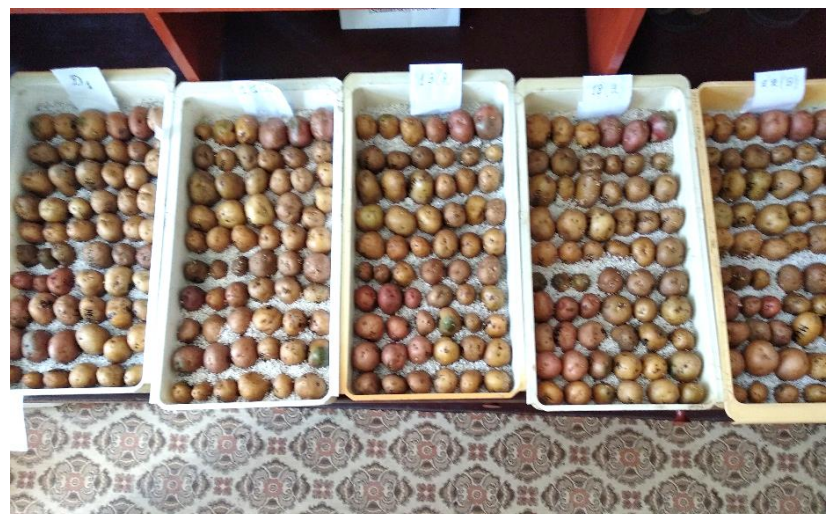

Рис. 1. Закладання лабораторних дослідів 3 оцінки та відбору сортів картоплі, стійких до раку, у субстраті ґрунт/перліт із використанням зимових зо0спор Synchytrium endobioticum (Schilb.) Perc.

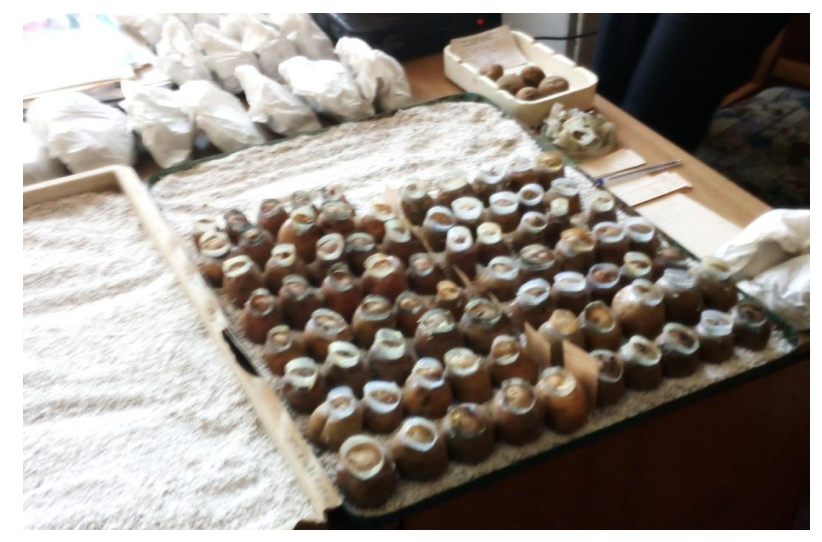

Рис. 2. Підготовка зразків картоплі для зараження зооспорами зі свіжих ракових наростів Synchytrium endobioticum (Schilb.) Perc.

літні зооспори збудника (рис. 2). Для стимулювання зараження зразки інкубували в клімокамері за температури $11^{\circ} \mathrm{C}$. Через 24 години з бульб картоплі знімали паперові кільця і продовжували інкубування у клімокамері за температури $17-18^{\circ} \mathrm{C}$, вологості $80 \%$ упродовж 20 діб без освітлення. Після закінчення вказаного терміну визначали реакцію зразків картоплі на зараження патогеном (рис. 3). Для цього паростки картоплі аналізували під мікроскопом (15x10) марки BioLight 300 (DELTA optical, Польща) і визначали ступінь ураження за такою шкалою: А - суцільна некротизована тканина, ультрастійкий; В некротизована тканина, стійкий; C - поодинокі соруси, некрози, слабостійкий; D - щільні соруси з деформацією паростка картоплі, сприйняливий; E - деформація паростка, раковий наріст, сприйнятливий.

Загальний бал (М) ураження сортів картоплі визначали за фрормулою:

$$
M=[A+2 B+3 C+4 D+5 E] / n,
$$

де A, B, C, D, E - ступінь ураження; 1, 2, 3, 4, 5 - кількість бульб, що отримали відповідний ступінь ураження; $\mathrm{n}$ - загальна кількість заражених бульб картоплі дослідного зразка. 


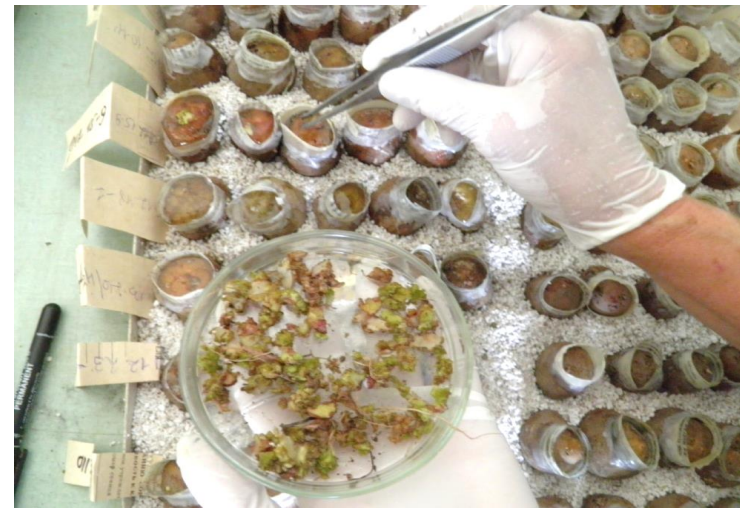

Рис. 3. Зараження зразків картоплі зооспорами зі свіжих ракових наростів Synchytrium endobioticum (Schilb.) Perc.

\begin{tabular}{llllllllllll}
\hline K & O & O & O & O & O & O & O & O & O & O \\
1 & & O & O & O & O & O & O & O & O & O & O \\
2 & & O & O & O & O & O & O & O & O & O & O \\
3 & & O & O & O & O & O & O & O & O & O & O \\
4 & O & O & O & O & O & O & O & O & O & O \\
K & O & O & O & O & O & O & O & O & O & O
\end{tabular}

Puc. 4. Схема закладання польових дослідів:

1, 2, 3, 4 - зразки картоплі; $К$ - контрольний сорт Поліська рожева
У разі визначення загального ступеня ураження 1, 2 чи 3 дослідний зразок уважали стійким до збудника раку ( $R$ - resistant ); ступенів 4 чи 5 - сприйнятливим (S - susceptible) [23].

Третій етап досліджень - це оцінка на стійкість до раку у польових умовах. Проводилася така оцінка на природному інфекційному фоні у вогнищах розповсюдження патогену звичайного (Д 1$)$ патотипу в н. п. Берегомет Вижницького району Чернівецької області; до агресивних патотипів - у н. п. Майдан Міжгірського району (11 патотипів), у м. Рахові (13 патотипів), с. Ясіня (18 патотипів) Рахівського району Закарпатської області і в н. п. Бистрець (22 патотипи) Верховинського району Івано-Франківської області. Дослід закладали в трьохразовій повторності (рис. 4); як позитивний контроль використовували сприйнятливий до всіх патотипів раку картоплі сорт Поліська рожева, негативного - сорт картоплі Божедар, який не уражається жодним патотипом збудника раку в Україні.

За результатами проведених досліджень 3 визначення стійкості до звичайного патотипу збудника раку у лабораторних та польових умовах під час зараження зимовими та літніми зооспорами хвороби з 15 зразків картоплі не уразився жоден зразок і всі отримали оцінку стійких (табл. 1, рис. 5, 6).

Відзначено лише ураження позитивного контрольного сорту картоплі Поліська рожева (100\%) як у лабораторних (рис. 7), так і у польових умовах (рис. 8).

Під час відбору сортів картоплі з комплексною стійкістю до всіх патотипів раку, що існують в Україні, відібрано три сорти картоплі: Родинна та Містерія селекції Інституту картоплярства НААН та Княжа селекції Львівського національного аграрного університету; три

Таблиця 1 - Результати оцінки та відбору сортів картоплі, стійких до звичайного та чотирьох агресивних патотипів збудника раку, внесених до Державного реєстру сортів рослин, придатних для поширення в Україні (2019-2020 рр.)

\begin{tabular}{|c|c|c|c|c|c|c|c|c|}
\hline \multirow{2}{*}{$\begin{array}{l}\text { № } \\
\Pi / \Pi\end{array}$} & \multirow{2}{*}{ № заявки } & \multirow{2}{*}{$\begin{array}{l}\text { Назва } \\
\text { сорту }\end{array}$} & \multirow{2}{*}{ Власник, країна } & \multicolumn{5}{|c|}{$\begin{array}{c}\text { Результати випробувань на стійкість до звичайного } \\
\text { та агресивних патотипів збудника раку }\end{array}$} \\
\hline & & & & Д1 & Міжгір'я (11) & $\begin{array}{c}\text { Paxiв } \\
(13)\end{array}$ & $\begin{array}{l}\text { Ясіня } \\
\text { (18) }\end{array}$ & $\begin{array}{c}\text { Бистрець } \\
\text { (22) }\end{array}$ \\
\hline 1 & 18088018 & 7 dopp 7 & Ден Хартіг Б.В., Нідерланди & - & + & - & - & - \\
\hline 2 & 18088023 & Раномі & Агріко Б.В., Нідерланди & - & + & - & - & - \\
\hline 3 & 19088001 & Шері & Жермікопа Брідінг САС,Франція & - & - & + & - & - \\
\hline 4 & 18088020 & Алюетт & Агріко Б.В., Нідерланди & - & - & - & - & - \\
\hline 5 & 18088024 & Лаундин & Агріко Б.В., Нідерланди & - & - & - & - & - \\
\hline 6 & 18088016 & Містерія & Інститут картоплярства НААН, Україна & - & - & - & - & - \\
\hline 7 & 18088021 & Парадізо & Агріко Б.В., Нідерланди & - & - & + & - & - \\
\hline 8 & 18088019 & Родріга & Солана Гмбх унд Ко. КГ, Німеччина & - & - & + & - & - \\
\hline 9 & 18088022 & Фонтане & Агріко Б.В., Нідерланди & - & - & - & - & - \\
\hline 10 & 17088011 & Житниця & Інститут картоплярства НААН, Україна & - & - & - & + & - \\
\hline 11 & 17088005 & Княжа & Львівський НАУ, Україна & - & - & - & - & - \\
\hline 12 & 17088010 & Ліллі & Солана Гмбхунд Ко. КГ, Німеччина & - & + & - & - & - \\
\hline 13 & 17088014 & Опілля & Інститут картоплярства НААН, Україна & - & + & - & + & - \\
\hline 14 & 17088009 & Прада & Ден Хартіг Б.В., Нідерланди & - & + & + & + & + \\
\hline 15 & 17088012 & Родинна & Інститут картоплярства НААН, Україна & - & - & - & - & - \\
\hline 16 & $\begin{array}{l}\text { Позитив. } \\
\text { контроль }\end{array}$ & $\begin{array}{l}\text { Поліська } \\
\text { рожева }\end{array}$ & Інститут картоплярства НААН, Україна & + & + & + & + & + \\
\hline 17 & $\begin{array}{l}\text { Негатив. } \\
\text { контроль }\end{array}$ & Божедар & Інститут картоплярства НААН, Україна & - & - & - & - & - \\
\hline & Всього: & $\begin{array}{l}\text { ст./спр. } \\
\text { \% стійких }\end{array}$ & & $\begin{array}{c}15 / 0 \\
(100 \%)\end{array}$ & $\begin{array}{c}10 / 5 \\
(66,6 \%)\end{array}$ & $\begin{array}{c}11 / 4 \\
(73,3 \%)\end{array}$ & $\begin{array}{c}12 / 3(80,0) \\
14 / 1(93,3 \%) \\
\end{array}$ & \\
\hline
\end{tabular}

Примітка: + - ураження патотипами збудника раку; - - відсутність ураження патотипами збудника раку 


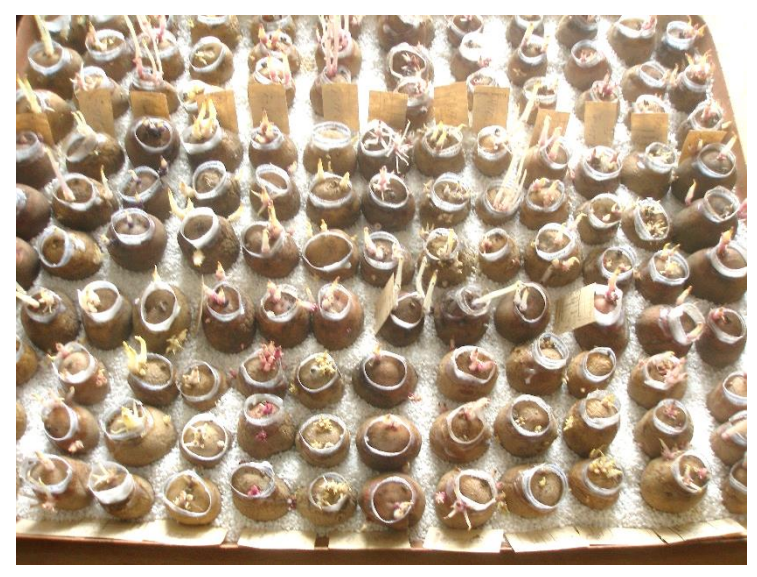

Рис. 5. Результати випробування сортів картоплі за ураження літніми зооспорами звичайного патотипу збудника раку Synchytrium endobioticum Schilbersky Perc.

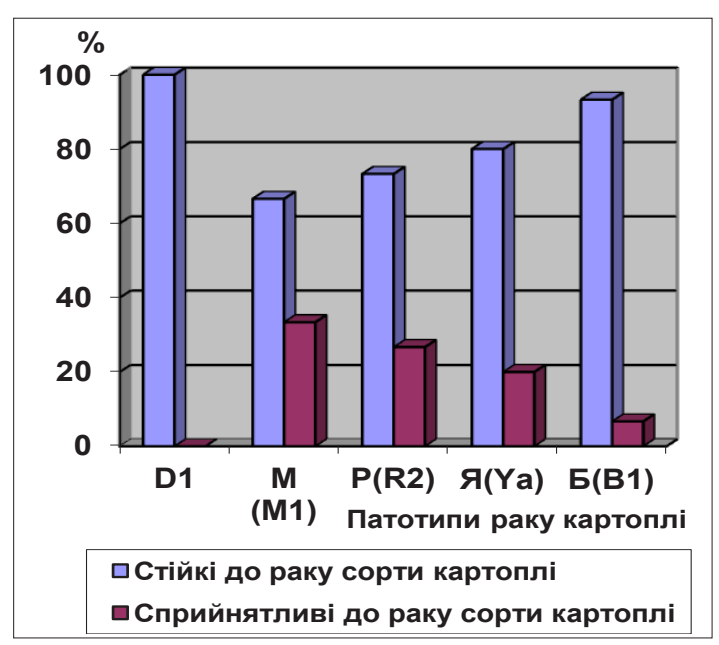

Puc. 6. Результати випробування сортів картоплі до звичайного патотипу збудника раку Synchytrium endobioticum (Schilb.) Perc.

сорти картоплі - Алюетт, Лаундин та Фонтане фірми «Агріко Б.В.», Нідерланди.

У результаті випробування до 11(M1) - Міжгірського агресивного патотипу в лабораторних та польових умовах із п'ятнадцяти зразків картоплі десять отримали оцінку стійких (66,6\%): чотири сорти картоплі української селекції Житниця, Містерія, Княжа та Родинна та шість сортів картоплі іноземної селекції: Алюетт, Лаундин, Парадізо, Фонтане фрірми «Агріко Б.В.», Нідерланди; Шері фрірми «Жермікопа Брідінг САС», Франція та Родріга фрірми 2Солана ГмбХ унд Ко, КГ.», Німеччина (рис. 6). Сорти картоплі 7 фор 7, Раномі, Опілля, Ліллі та Прада отримали оцінку сприйнятливих до даного патотипу.

Під час визначення стійкості сортів картоплі до 13 (R2) - (Рахівського) агресивного патотипу не уразилися одинадцять сортів (73,3\%): пять сортів картоплі української селекції: Житниця, Містерія, Княжа, Родинна та Опілля; 7 фор 7 фрірми «Ден Хартіг Б.В.», Раномі,

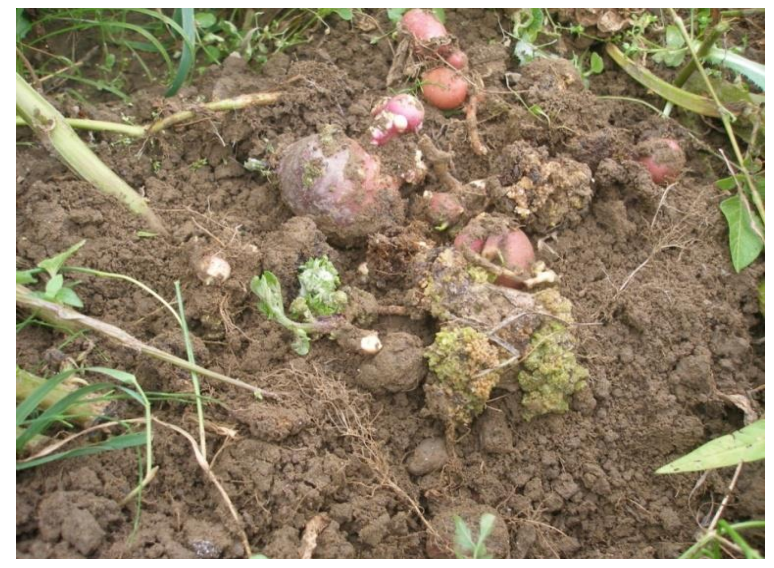

Рис. 8. Контрольний сорт картоплі Поліська рожева, уражений збудником раку в польових умовах

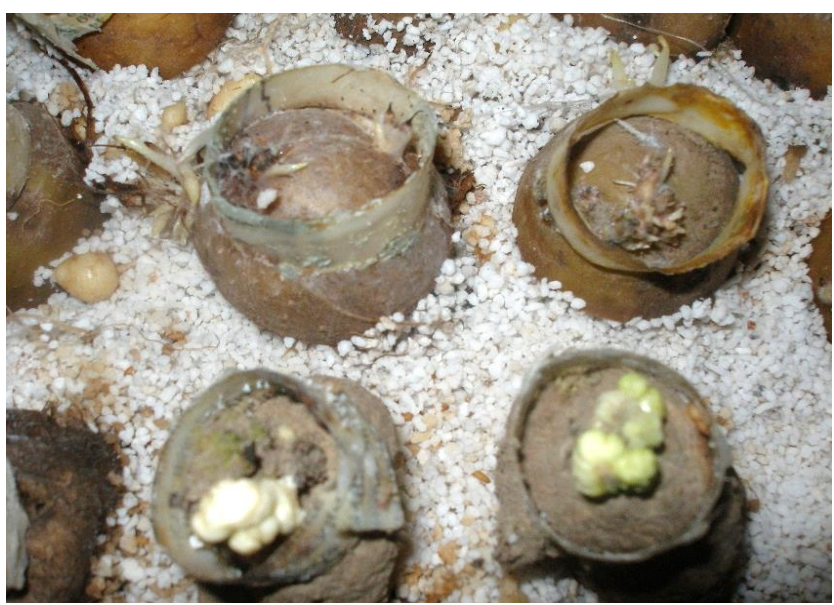

Рuc. 7. Контрольний сорт картоплі

Поліська рожева, уражений літніми зооспорами звичайного патотипу збудника раку Synchytrium endobioticum (Schilb.) Perc.

Алюетт, Лаундин та Фонтане фірми «Агріко Б.В.», Нідерланди (рис. 6). Сорти Шері, Парадізо, Родріга та Прада уразилися даним агресивним патотипом.

У результаті відбору селекційного матеріалу картоплі на стійкість до 18 (Үа) - Ясінівського агресивного патотипу відібрано дванадцять зразків (80,0\%): Містерія, Княжа та Родинна української селекції; 7 фор 7 фрірми «Ден Хартіг Б.В.», Нідерланди; Раномі, Алюетт, Лаундин, Фонтане фрірми «Агріко Б.В.», Нідерланди; Шері фрірми «Жермікопа Брідінг САС», Франція; Родріга та Ліллі фрірми «Солана ГмбХ унд Ко, КГ.», Німеччина. Сорти картоплі Житниця, Опілля та Прада показали позитивну реакцію на зараження даним патотипом (рис. 6).

Найвищий відсоток стійких сортів (93,3\%) отримано у результаті випробування до 22 (В1) - Бистрецького агресивного патотипу. Із п'ятнадцяти зразків картоплі чотирнадцять отримали оцінку стійких: п'ять сортів картоплі української селекції: Містерія, Житниця, Княжа, Родинна та Опілля; дев'ять сортів іноземної селекції: 
7 фор 7 фрірми «Ден Хартіг Б.В.», Нідерланди; Раномі, Алюетт, Лаундин, Парадізо, Фонтане фрірми «Агріко Б.В.», Нідерланди; Шері фрірми «Жермікопа Брідінг САС», Франція; Родріга та Ліллі фрірми «Солана ГмбХ унд Ко, КГ.», Німеччина (рис. 6). Даним патотипом уразився лише один сорт картоплі - Прада фірми «Ден Хартіг Б.В.», Нідерланди.

Сорти картоплі, які не уразились патотипами збудника раку, рекомендовані для занесення до Державного реєстру сортів рослин, придатних для поширення в Україні, з метою впровадження у вогнищах хвороби, а селекціонерам рекомендовано використовувати такі сорти у селекційному процесі для схрещування як джерел стійкості й отримання стійких до хвороби нащадків картоплі.

Висновки. У результаті проведених лабораторних та польових досліджень з оцінки та відбору сортів картоплі з комплексною стійкістю до всіх патотипів раку, що існують в Україні, відібрано три сорти картоплі: Родинна та Містерія селекції Інституту картоплярства НААН та Княжа селекції Львівського національного аграрного університету; три сорти картоплі - Алюетт, Лаундин та Фонтане фрірми «Агріко Б.В.», Нідерланди.

Під час відбору сортів картоплі, стійких до звичайного патотипу Д1 збудника раку, з п'ятнадцяти сортів картоплі української та іноземної селекції не уразився жоден зразок і всі (100\%) отримали оцінку стійких.

У результаті випробування до 11 (М1) - Міжгірського агресивного патотипу в лабораторних та польових умовах із п'ятнадцяти зразків картоплі десять отримали оцінку стійких, що становило $66,6 \%$.

Під час оцінці стійкості сортів картоплі до 13 (R2) (Рахівського) агресивного патотипу відібрано одинадцять сортів (73,3\%).

Під час випробування селекційного матеріалу картоплі на стійкість до 18 (Ya) - Ясінівського агресивного патотипу відібрано дванадцять зразків, або 80,0\%.

Найвищий відсоток стійких сортів $(93,3 \%)$ отримано у результаті випробування до 22 (В1) - Бистрецького агресивного патотипу. Із п'ятнадцяти зразків картоплі чотирнадцять отримали оцінку стійких: п'ять сортів картоплі української селекції та дев'ять сортів - іноземної.

Ураження позитивного контрольного сорту картоплі Поліська рожева у лабораторних та польових умовах становило 100\%; негативного контрольного сорту Божедар - 0\%.

Сорти картоплі, які не уразилися патотипами збудника раку, рекомендовані для занесення до Державного реєстру сортів рослин, придатних для поширення в Україні з метою впровадження у вогнищах хвороби, а селекціонерам рекомендовано використовувати такі сорти у селекційному процесі для схрещування як джерел стійкості й отримання стійких до хвороби нащадків картоплі.

\section{СПИСОК ВИКОРИСТАНОÏ ЛІТЕРАТУРИ:}

1. Бондарчук А.А. Наукові основі насінництва картоплі в Україні. Біла Церква, 2010. 400 с.

2. Державна служба статистики України. Рослинництво України. Статистичний збірник. Київ, 2019. C. 134-135. URL: http://www.ukrstat.gov.ua/ druk/publicat/kat_u/2019/zb/04/zb_rosl_2018.pdf (дата звернення: 20.01.2021).

3. Potato soil-borne diseases / M. Fiers et al. Agronomy for Sustainable Development. 2012. № 32(1). P. 93-132. DOI: https://doi.org/ 10.1007/s13593-011-0035-z.

4. Мельник П.О. Етіологія раку картоплі, біоекологічне обґрунтування заходів його профілактики та обмеження розвитку. Чернівці : Прут, 2003. 284 с.

5. EPPO Global Database (available online). 2018. URL: https://gd.eppo.int (дата звернення: 21. 10.2020).

6. History of potato wart disease in Europe - a proposal for harmonisation in defining pathotypes / R.P. Baayen et al. European Journal Plant Pathology. 2006. № 116. P. 21-31. DOI: https://doi.org/10.1007/ s10658-006-9039-y.

7. Bojnansky V. Potato wart pathotypes in Europe from an ecological point of view. Bulletin OEPP/EPPO Bulletin. 1984. Vol. 14.(2) P. 141-146. DOI: https:// doi.org/10.1111/j.1365-2338.1984.tb01861.x.

8. Boberg J., Björklund N. Synchytrium endobioticum pathotypes, resistance of Solanum tuberosum and management. Reportby UnitforRiskAssessment of Plant Pests at the Swedish University of Agricultural Sciences. 2018. 38 p. URL: https://www.slu.se/globalassets/ ew/org/centrb/riskv/pub/rapport-synchytriumendobioticum_ Я21sept2018.pdf (дата звернення: 30.01.2021).

9. Przetakiewicz J. Sampling, maintenance and pathotype identification Synchytrium endobioticum (Schilb.) Perc. Plant Breeding and Seed Science. 2017. Vol. 76. P. 29-36. DOI: https://doi.org/ 10.1515/ plass-2017-0018.

10. Langerfeld E.H. Stachewicz H., Rintelen J. Pathotypes of Synchytrium endobioticum in Germany. Bulletin OEPP/EPPO Bulletin. 1994. № 24. P. 799-804. DOI: https://doi.org/10.1111/j.1365-2338.1994.tb01100.x.

11. Potoček J., Krajiččová K., Krejcar Z. Identification of new Synchytrium endobioticum (Schilb.) Perc. pathotypes in Czech Republic. Ochrana Rostlin. 1991. № 27. P. 191-205. DOI: https://doi.org/agris.fao.org/ agris-search/search.DOI:recordID=CS9200002.

12. Identification of pathotypes of Synchytrium endobioticum found in infested fields in Turkey / E. Cakir et al. Bulletin OEPP/ EPPO Bulletin. 2009. № 39. P. 175-178. DOI: https://doi.org/10.1111/j.1365-2338.2009.02285.x.

13. Occurrence of the Pathotype 38 of Synchytrium Endobioticum in Khulo Municipality of Georgia / S. Ghoghoberidze et al. Bulletin of the Georgian national academy of science. 2020. Vol 14. № 1. P. 114-119. URL: C:/Users/User/Downloads/17_Ghoghoberidze\%20 et\%20al_Agrarian\%20Sciences.pdf (дата звернення: 25.01.2021).

14. Огляд поширення карантинних організмів в Україні станом на 01.01.2020. URL: http://www.consumer.gov.ua/ ContentPages/Oglyad_Poshirennya_Karantinnikh Organizmiv_V_Ukraini/219 (дата звернення: 25.01.2021).

15. Фітосанітарний станвогнищраку картоплі Synchytrium endobioticum (Schilbersky) Percival в Карпатському регіоні України / / А.Г. Зеля та ін. Карантин і захист рослин. 2020. № 4-6(261). C. 9-15. DOI: https://doi. org/ 1036495/2312-0614/2020/4-6.9-15.

16. Screening of potato varieties for multiple resistance to Synchytrium endobioticum in Western region of Ukraine / A.G. Zelya et al. Agricultural Science and 
Practice. 2018. № 3. P. 3-11. DOI: https://doi.org/ 10.15407/agrisp 5.03.003.

17. Зеля А.Г., Олійник Т.М., Зеля Г.В. Відбір джерел стійкості картоплі до збудника раку Synchytrium endobioticum (Schilbersky) Percival. Передгірне та гірське землеробство і тваринництво. 2020. Вип 67(2). С. 75-91. DOI: https://doi.org/ 10.32636/01308521.2020-(67)-2-5.

18. Фурдига М.М. Інноваційний розвиток насінництва картоплі в Україні. URL: http://naas.gov.ua/ news/?ELEMENT_ID=6578 (дата звернення: 02.02.2021)

19. Семенчук В.Г. Продуктивність насіннєвої картоплі сортів різних груп стиглості в умовах Південно-західної частини Лісостепу України. Передгірне та гірське землеробство і тваринництво. 2020. Вип 67(2). С. 170-181. DOI: 10.32636/01308521.2020-(67)-2-11.

20. EPPO Standard PM 7/28/1 Synchytrium endobioticum. Bulletin OEPP/EPPO Bulletin. 2004. Vol. 34. № 2. P. 213-218. URL: https://www.furs.si/law/eppo/ zvr/ENG/EPPO2004/diag_protokoli_PM7/pm-28(1). pdf (дата звернення: 30.01.2021).

21. EPPO Standard PM $7 / 28 / 2$ Synchytrium endobioticum. Bulletin OEPP/EPPO Bulletin. 2017. Vol. 47. № 3 . P. 420-440. URL: https://onlinelibrary.wiley.com/ doi/epdf/10.1111/epp.12588 (дата звернення: 30.01.2021).

22. Спосіб створення штучного інфрекційного фрону гриба Synchytrium endobioticum (Schilb.) / А.Г. Зеля та ін. Percival для визначення стійкості картоплі до раку: Пат. 115654 Україна. № и 201610784; заяв. 27.10.2016; опубл. 25.04.2017. Бюл. № 8.

23. Спосіб визначення стійкості картоплі до раку Synchytrium endobioticum (Schilbersky) Percival та іiї успадкування методом спектрофотометрії / А.Г. Зеля та ін. Пат. 126988 Україна. № u 201801646; заявл. 19.02.2018; опубл. 10.07.2018. Бюл. № 13.

\section{REFERENCES:}

1. Bondarchuk, A.A. (2010). Naukovi osnovy nasinnytstva kartopli $v$ Ukraini [Scientific fundamentals of potatoe seed produbtion sn Ukraine]. Bila Tserkva : N.p. [in Ukrainian].

2. Derzhavna sluzhba statystyky Ukrayiny. Roslynnycztvo Ukrayiny. [State Statistics Service of Ukraine. Crop production of Ukraine]. (2019). Statystychnyj zbirnyk Statistical collection, 134-135. Kyiv URL: http://www. ukrstat.gov.ua/druk/publicat/kat_u/2019/zb/04/zb_ rosl_2018.pdf._[in Ukrainian].

3. Fiers, M. et al. (2012). Potato soil-borne diseases. Agronomy for Sustainable Development, 32(1), 93-132. DOI: https://doi.org/10.1007/s13593-011-0035-z [in English].

4. Melnyk, P.O. (2003). Etiologiya raku kartopli, bioekologichne obgruntuvannya zaxodiv jogo profilaktyky ta obmezhennya rozvytku [Potato wart etiology, bioecological justification of measures, it's prevention and restriction of development]. Chernivci : Prut URL: https://gd.eppo.int [in Ukrainian].

5. EPPO (2018). Global Database (available online). URL: https://gd.eppo.int. [in English].

6. Baayen, R.P. et al. (2006). History of potato wart disease in Europe - a proposal for harmonisation in defining pathotypes. European Journal Plant Pathology, 116, 21-31. DOI: https://doi.org/10.1007/s10658-006-9039-y [in English].

7. Bojnansky, V. (1984). Potato wart pathotypes in Europe from an ecological point of view. Bulletin OEPP/EPPO Bulletin, 141-146. DOI:https://doi. org/10.1111/j.1365-2338.1984.tb01861.x [in English].

8. Boberg, J. \& Björklund, N. (2018). Synchytrium endobioticum - pathotypes, resistance of Solanum tuberosum and management. Report by Unit for Risk Assessment of Plant Pests at the Swedish University of Agricultural Sciences. 38 p. URL: https://www. slu.se/globalassets/ew/org/centrb/riskv/pub/rapportsynchytrium-endobioticum_21sept2018.pdf [in English].

9. Przetakiewicz, J. (2017). Sampling, maintenance and pathotype identification Synchytrium endobioticum (Schilb.) Perc. Plant Breeding and Seed Science, 29-36. DOI: https://10.1515/plass-2017-0018 [in English].

10. Langerfeld, E.H., Stachewicz, H. \& Rintelen, J. (1994). Pathotypes of Synchytrium endobioticum in Germany. Bulletin OEPP/EPPO Bulletin, 799-804 DOI: https://10.1111/j.1365-2338.1994.tb01100.x [in English].

11. Potoček, J., Krajíčková, K. \& Krejcar, Z. (1991). Identification of new Synchytrium endobioticum (Schilb.) Perc. pathotypes in Czech Republic. Ochrana Rostlin, 191-205. URL: http://agris.fao.org/agrissearch/search. DOI:recordID=CS9200002 [in English].

12. Cakir, E. et al. (2009). Identification of pathotypes of Synchytrium endobioticum found in infested fields in Turkey. Bulletin OEPP/EPPO Bulletin, 175-178. DOI: https://10.1111/j.1365-2338.2009.02285.x [in English].

13. Ghoghoberidze, S. et al. (2020). Occurrence of the Pathotype 38 of Synchytrium Endobioticum in Khulo Municipality of Georgia. Bulletin of the Georgian national academy of science, 114-119. URL:/Users/ User/Downloads/17_Ghoghoberidze\%20et\%20al_ Agrarian\%20Sciences.pdf [in English].

14. Oglyad poshyrennya karantynnyx organizmiv v Ukrayini stanom na 01.01.2020 [Review of quarantine pests spread in Ukraine on 01.01.2020]. URL: http://www. consumer.gov.ua/ContentPages/Oglyad_Poshirennya Karantinnikh_Organizmiv_V_Ukraini/219 [in Ukrainian].

15. Zelya, A.G. et al. (2020). Fitosanitarnyj stan vognyshh raku kartopli Synchytrium endobioticum (Schilbersky) Percival v Karpatskomu regioni Ukrayiny [The phytosanitary term of old sources potato wart Synchytrium endobioticum (Schilb.) Perc. in Ukraine]. Karantin I zahyst Roslyn Quarantine and plant protection, 4-6 (261), 9-15. DOI: https:// 1036495/2312-0614/2020/4-6.9-15 [in Ukrainian].

16. Zelya, A.G. et al. (2018). Screening of potato varieties for multiple resistance to Synchytrium endobioticum in Western region of Ukraine. Agricultural Science and Practice, 3, 3-11. DOI: https://10.15407/agrisp 5.03.003 [in English].

17. Zelya, A.G., Olijnik, T.M. \& Zelya, G.V. (2020). Vidbir dzherel stijkosti kartopli do zbudnyka raku Synchytrium endobioticum (Schilbersky) Percival [Selection of sources of potato resistance to wart Synchytrium endobioticum (Schilbersky) Percival]. Peredgirne ta girske zemlerobstvo $i$ tvarinnictvo - Foothill and mountain agriculture and animal husbandry, 67, (2), 75-91. DOI: https://10.32636/01308521.2020(67)-2-5_[in Ukrainian]. 
18. Furdiga, M.M. (2021). Inovacijnyj rozvytok nasinnycztva kartopli $\vee$ Ukrayini [Innovative development of potato seed in Ukraine]. URL: http://naas.gov.ua/ news/?ELEMENT_ID=6578 [in Ukrainian].

19. Semenchuk, V. G. (2020). Produktyvnist nasinnyevoyi kartopli sortiv riznyx grup styglosti v umovax Pivdennozaxidnoyi chastyny Lisostepu Ukrayiny [Seed potato productivity of varieties of different ripeness groups in condition of south-western part of Forest-Steppe of Ukraine]. Peredgirne ta girske zemlerobstvo i tvarinnictvo Foothill and mountain agriculture and animal husbandry, 67, (2), 170-181 DOI: https://10.32636/01308521.2020(67)-2-11 [in Ukrainian].

20. EPPO Standard PM 7/28/1 Synchytrium endobioticum (2004). Bulletin OEPP/EPPO Bulletin, 34, 2, 213-218. URL: https://www.furs.si/law/eppo/zvr/ENG/EPPO2004/ diag_protokoli_PM7/pm 7 -28(1).pdf [in English].

21. EPPO Standard PM $7 / 28 / 2$ Synchytrium endobioticum. (2017). Bulletin OEPP/EPPO Bulletin. 47, 3б 420-440. URL: https://onlinelibrary.wiley.com/doi/epdf/10.1111/ epp.12588 [in English].

22. Zelya, A.G., Gunchak, V.M., Zelya, G.V., Olijnyk, T.M., Furdyga, M.M. \& Zaxarchuk N.A. (2016). Sposib stvorennya shtuchnogo infekcijnogo fonu gryba Synchytrium endobioticum (Schilb.) Percival dlya vyznachennya stijkosti kartopli do raku: Patent 115654 na korysnu model [The technique creation for artificial background of fungi Synchytrium endobioticum (Schilb.) Percival for potato resistance determining to wart : Patent 115654 for a utility model]. № u 201610784 Bull. No. 8 [in Ukrainian].

23. Zelya, A.G., Gunchak, V.M., Zelya, G.V., Olijnyk, T.M., Pylypenko, L.A., Borzyx, O.I., Bondarchuk, A.A., Furdyga, M.M., Zaxarchuk, N.A., Pysarenko, N.V., Ilchuk, Yu.R., Kushnir, O.V., Vorobecz, G.I. \& Pshenychnyj, O.O. (2018). Sposib vyznachennya stijkosti kartopli do raku Synchytrium endobioticum (Schilbersky) Percival ta yiyi uspadkuvannya metodom spektrofotometriyi [The technique determination for resistance potato to wart Synchytrium endobioticum (Schilbersky) Percival and it's inheriting by spectrofotometry method:Patent126988forautilitymodel]. №u201801646Bull. No. 13 [in Ukrainian].

Зеля А.Г., Зеля Г.В., Макар Т.Й., Сонець Т.Д., Києнко З.Б. Відбір сортів картоплі 3 комплексною стійкістю до збудника раку Synchytrium endobioticum Schilbersky Perc.

Мета. Оцінити та відібрати сорти картоплі української та іноземної селекції з комплексною стійкістю до всіх патотипів раку, що існують в Україні, та виділити стійкі сорти для занесення до Державного реєстру сортів рослин, придатних для поширення в Україні, які можна впровадити у вогнищах хвороби. Методи. У дослідження залучено 15 сортів картоплі: 5 сортів української селекції та 10 - іноземної. Оцінку селекційного матеріалу на стійкість до звичайного 1(D1) і агресивних патотипів збудника раку картоплі проводили в лабораторних умовах Української науково-дослідної станції карантину рослин ІЗР НААН на штучному інфекційному фоні згідно з «Методикою оцінки та відбору селекційного матеріалу картоплі, стійкого до раку Synchytrium endobioticum (Schilb.) Perc., гармонізованою з вимогами ЄC» у лабораторних та польових умовах. Результати. У результаті проведених лабораторних та польових досліджень з оцінки та відбору сортів картоплі з комплексною стійкістю до всіх патотипів раку відібрано три сорти картоплі української селекції: Родинна та Містерія селекції Інституту картоплярства НААН і Княжа селекції Львівського національного аграрного університету; три сорти картоплі Алюетт, Лаундин та Фонтане фрірми «Агріко Б.В.», Нідерланди. Усі досліджувані сорти $(100 \%)$ виявилися стійкими до звичайного патотипу; до 11 (Міжгірського) патотипу відібрано 66,6\% стійких сортів; стійких до 13 (Рахівського) агресивного патотипу виявлено 73,3\%; до 18 (Ясінівського) - 80,0\%; до 22 (Бистрецького) - 93,3\%. Ураження позитивного контрольного сорту картоплі Поліська рожева у лабораторних та польових умовах становило $100 \%$; негативного контрольного сорту Божедар - 0\%. Висновки. Сорти картоплі, які не уразилися патотипами збудника раку, рекомендовано для занесення до Державного реєстру сортів рослин, придатних для поширення в Україні та для впровадження у вогнищах хвороби.

Ключові слова: збудник раку, патотипи, сорти картоплі, випробування, стійкість, оцінка, відбір.

Zelya A.G., Zelya G.V., Makar T.Y., Sonets T.D., Kyenko Z.B. The choice of potato varieties with complex resistance to wart causative agent Synchytrium endobioticum Schilbersky Perc.

Goal. To evaluate and to select varieties of Ukrainian and foreign breeding with complex resistance to all wart pathotypes, which exist in Ukraine and to determine resistant varieties for put into the State Register of Plant Varieties Suitablefor Dissemination in Ukraine. These varieties may be used in diseases sources. Materials and methods. There were used 15 potato varieties: 5 potato varieties of Ukrainian breeding and 10 foreign for researches. The evaluation of breeding material on resistance to common pathotype 1(D1) and aggressive pathotypes of potato wart causative agent conducted in laboratory terms of Ukrainian scienceresearch plant quarantine station IPP NAAS on artificial infectious background as per "Technique for evaluation and choice potato breeding material resistant to wart Synchytrium endobioticum (Schilb.) Perc, harmonized with EU requirements. Results. The following potato varieties: three potato varieties of Ukrainian breeding: Rodynna and Knyazha breeding by Lviv National Agrarian university; three potato varieties of foreign breeding: Alouette, Laundin and Fontane by company Agrico B.V.,Netherlands have had a complex resistance to all potato wart pathotypes by the results of all conducted laboratory and field researches. All researched varieties $(100 \%)$ showed resistance to common pathotype; the resistant varieties $66,6 \%$ selected on resistance to 11 (Mizhirrya) pathotype; resistant to 13 (Rachiv) aggressive pathotype showed 73,3\%;80\% resistant to 18 (Yasinivsky); $93,3 \%$ resistant to 22 (Bystrytsya). The positive inspected potato variety Poliska rozheva defeating was consisted of $100 \%$, negative inspected potato variety Bozhedar was consisted of $0 \%$. Conclusions. We propose non-defeating potato varieties to put into the State Register of Plant Varieties Suitablefor Dissemination in Ukraine for disease sources implementation.

Key word: potato wart, pathotypes, potato varieties, implementation, resistance. 